\title{
Establishing a Dynamic Capital Structure Model for Company Sustainability Performance Using Data Mining Techniques
}

\author{
Mu-Jung Huang ${ }^{1, *}$, Kuo-Chih Cheng ${ }^{1}$, Ching-Ju Huang ${ }^{1}$, Kun-Meng Lin ${ }^{2}$, Huo-Ming Wang ${ }^{2}$, \\ Cheng-Kuo Chuang ${ }^{2}$ and Ming-Cheng $\mathrm{Wu}^{2}$ \\ 1 Department of Accounting, National Changhua University of Education, Changhua 500, Taiwan; \\ h12343562@ms46.hinet.net (K.-C.C.); mjhuang8601@gmail.com (C.-J.H.) \\ 2 Department of Finance, National Changhua University of Education, Changhua 500, Taiwan; \\ kmhongsang@yahoo.com.tw (K.-M.L.); bikewang@gmail.com (H.-M.W.); chchuang@gmail.com (C.-K.C.); \\ mcwu@cc.ncue.edu.tw (M.-C.W.) \\ * Correspondence: mjhuang@cc.ncue.edu.tw
}

check for updates

Citation: Huang, M.-J.; Cheng, K.-C.; Huang, C.-J.; Lin, K.-M.; Wang, H.-M.; Chuang, C.-K.; Wu, M.-C.

Establishing a Dynamic Capital Structure Model for Company Sustainability Performance Using Data Mining Techniques.

Sustainability 2021, 13, 6026. https:// doi.org/10.3390/su13116026

Academic Editor: Adam Smoliński

Received: 4 May 2021

Accepted: 24 May 2021

Published: 27 May 2021

Publisher's Note: MDPI stays neutral with regard to jurisdictional claims in published maps and institutional affiliations.

Copyright: (c) 2021 by the authors. Licensee MDPI, Basel, Switzerland. This article is an open access article distributed under the terms and conditions of the Creative Commons Attribution (CC BY) license (https:/ / creativecommons.org/licenses/by/ $4.0 /)$.

\begin{abstract}
In order to reconsider the changes of adjustment speed caused by the recapitalization cost, this research adopted dynamic capital structure theory with adjustment speed as one of the independent variables to analyze the relationship between capital structure and company performance. Instead of applying the commonly used regression models, this research used the decision tree C4.5 algorithm and association rules of priori algorithm. Taking the predictive models created by the decision tree as the main result and supporting it with association rules which help to explain the relationships between capital structure and company performance, this research shows how capital structure influences company performance. As the result presents, a company tends to have better performance when its debt ratio is low, and Tobin's $Q$ and ROA will turn worse as the ratio gets higher. However, maybe because of the financial leverage, ROE will not decrease when the ratio is high but will increase instead. In addition, this research found out that adjustment speed is negatively related to company performance, meaning that even though a company is more flexible in adjusting itself, it might still perform badly since it is deviating from its optimum leverage. This research found that not only capital structure, but other variables such as price-earnings ratio, research and development expense ratio, and dividend payout ratio also determine a company's performance.
\end{abstract}

Keywords: capital structure; company performance; data mining; decision tree; association rules

\section{Introduction}

The operating risks of a company can be divided into operational risks arising from the market and sales changes and financial risks resulting from the use of financial leverage [1,2]. Liabilities and equity are the main sources of operating capital for a company. The ratio of the two represents how much the company can get through the cost, which is the meaning of the capital structure [3]. In the past, scholars put forward many different views on the capital structure theory [4-6]. Among them, the representative ones are the capital structure irrelevance theory and the subsequent revised capital structure theory (MM theory) proposed by Modigliani and Miller [7], the theory of financing priority proposed by Myers and Majluf [8], and the theory of dynamic capital structure proposed by Fischer et al. [9]. However, the research conclusions made by these theories are inconsistent, so scholars continue to try various theories in an attempt to find theories that can fully explain the phenomenon of capital structure.

Since the definition of company performance is a composite assessment of how well an organization executes on its most important parameters, typically financial, market, and shareholder performance, a company must do its best to keep in an optimal capital structure that is the best mix of debt and equity financing that maximizes a company's market value while minimizing its cost of capital [10]. So far, although many scholars 
have studied capital structure, and the results show that the explanatory power of the dynamic model is better than the static model, there is no literature to explore whether the capital structure affects company performance because of its dynamic adjustment characteristics [10].

Ever since Durand [11] proposed the net income approach and net operating income approach in 1952, the debate of how capital structure effects company performance has not stopped. Even though experts still cannot reach a conclusion, most of the research supports that the two are in a negative relationship. However, in such research, recapitalization cost is usually ignored. Therefore, in order to reconsider the changes of adjustment speed caused by the recapitalization cost, this research adopted dynamic capital structure theory with adjustment speed as one of the independent variables, analyzing the relationship between capital structure and company performance [10,12].

In addition, with the advent of the "big data" era, the application of new technologies has become the key for companies to compete in the market. Through the so-called huge amount of data exploration, it will not only help companies make more accurate analyses of the collected information, but can also even use this result to predict the future $[13,14]$. In view of this, this research intends to apply data mining technology to explore the relationship between dynamic capital structure and company performance, and it is hoped that companies can have more efficient capital structure utilization. The main objectives of this study are as follows:

1. Using the decision tree method in data mining to explore the relationship between dynamic capital structure and company performance, this study examines whether the debt ratio that the company continuously adjusts over time to achieve the optimal capital structure is the determining factor of company performance.

2. Because the decision tree observes the overall rules in the form of a single variable, the association rules are also used to analyze whether there are hidden association rules between the variables. The company can be more efficient and improve company performance by using the rules.

\section{Literature Review}

\subsection{Dynamic Capital Structure}

Brennan and Schwartz [15] tried to use the tax shield benefits of company income tax and personal income tax to establish a dynamic value assessment model. In the study of Fischer et al. [9], according to the model derived by Kane et al. [16], the conditions for capital structure adjustment were relaxed, and it was assumed that the capital structure could be adjusted at any time and was no longer limited by the maturity of liabilities. Elsas and Florysiak [10] proposed a new unbiased estimator for adjustment speed in the presence of fractional dependent variables that also controls for unobserved heterogeneity and unbalanced panel data. The theory of dynamic capital structure laid the foundation for it. Fischer et al. [9] believe that even if the adjustment cost is very low, it will cause the company to deviate sharply from the optimal capital structure, and this cost will vary according to the characteristics of the company. Dynamic capital structure should be included in adjustment policies [12,17-19]. The characteristics of this dynamic model can be summarized as follows: 1 . The adjustment of capital structure is not limited by time. It is a continuous-time architecture model that can be adjusted at any time. 2. The adjustment of the optimal capital structure needs to consider the cost of capital structure adjustment. 3. The company will set an optimal capital structure adjustment policy in advance, including determining the upper and lower thresholds of the debt ratio and the optimal initial value that should be returned after the expenditure adjustment cost in order to maximize the benefits of leverage and the value of the company. When the debt ratio of a company changes due to fluctuations in the value of the asset over time, once the threshold is reached, the company will adjust the capital structure to return the debt ratio to the initial value set. 4 . The setting of the capital structure policy of a company will be affected by its characteristics. Therefore, companies with similar properties will usually also be affected 
by similar adjustment strategies. 5. In the theory of dynamic capital structure, since the optimal capital structure is a range value, it is observed at a certain point in time. The debt ratio does not represent the target capital structure for a certain period.

After Fischer et al. [9] put forward the theory of dynamic capital structure, many scholars have successively used this theory and then added their views to develop research models.

\subsection{The Relationship between Capital Structure and Company Performance}

The company's performance can be roughly divided into operating performance and market performance. Among them, the indicators of operating performance can be divided into financial and operational indicators. Financial indicators are used to measure whether a company's financial operations meet its set operating goals, such as return on assets, return on shareholders' equity, and return on investment. The operational indicators are inspections of the results of the product from research and development, through manufacturing, and to sales, such as product quality, marketing effectiveness, and market share. Usually when conducting research and measurement, financial indicators are used to represent business performance. Market performance is a measure of how much value the company considers in the financial market relative to the company's book value. It is often measured using the Tobin's Q ratio proposed by Nobel laureate James Tobin [19].

Titman and Wessels [20] used the concept of static exchange theory to explore the relationship between capital structure and company growth by using linear structural relations. His research divides the capital structure into long-term, short-term, and convertible company bonds. The research results show that there is a positive relationship between debt ratio and company growth.

Berger and Patti [21] used two opposing hypotheses to study the agency costs that the financial industry must bear in making financial structure decisions. The two hypotheses used in this study are the efficiency-risk hypothesis of preference for high debt ratios and the franchise-value hypothesis of preference for low debt ratios. Empirical findings have found that both phenomena coexist, and that the company's profit efficiency will gradually increase from the average of the financial leverage of the sample to the two sides. Dao and Ta [22] provided insights on the relationship between capital structure and performance of the company by employing a meta-analytical approach to obtain a synthesized result out of controversial studies as well as the sources for such inconsistencies.

\subsection{Data Mining}

Data mining is an automatic or semi-automatic process which integrates and analyzes the raw data to obtain the potential knowledge or new relationship [23]. Data mining, known as "knowledge discovery in databases", is the process of discovering interesting patterns in databases that are meaningful in decision-making and is also an application area that can provide significant competitive advantage to an organization [24-26]. Designing a framework for a knowledge discovery process is critical. Researchers have described a series of steps that constitute a knowledge discovery process, which range from a few steps to more sophisticated models such as the nine-step DM knowledge discovery process model by the authors of [27].

Generally speaking, data mining tasks can be classified into three main categories: prediction, association, and clustering. Prediction is commonly referred to as the act of telling about the future. Classification, or supervised induction, is to analyze the historical data stored in a database and generate a model that can predict future behavior. Association, or association rule learning in data mining, is well-researched technique for discovering interesting relationships among variables in big data. Two commonly used derivatives of association rule learning are link analysis and sequence mining. With link analysis, the linkage among many objects of interesting is discovered. With sequence mining, relationships are examined in terms of their order of occurrence to identified association over time. Algorithms used in association rules include the popular Apriori and FP-Growth [28]. 


\section{The Methodology}

\subsection{The Framework of Mining Dynamic Capital Structures and Company Performance}

As shown in Figure 1, this study uses data mining techniques and algorithms in the software Weka 3.8 to study the relationship between the company's dynamic capital structure and company performance. It is expected to provide companies with more efficient capital investment decisions and investors with investment decisions. The framework of this research mainly includes the following four parts:

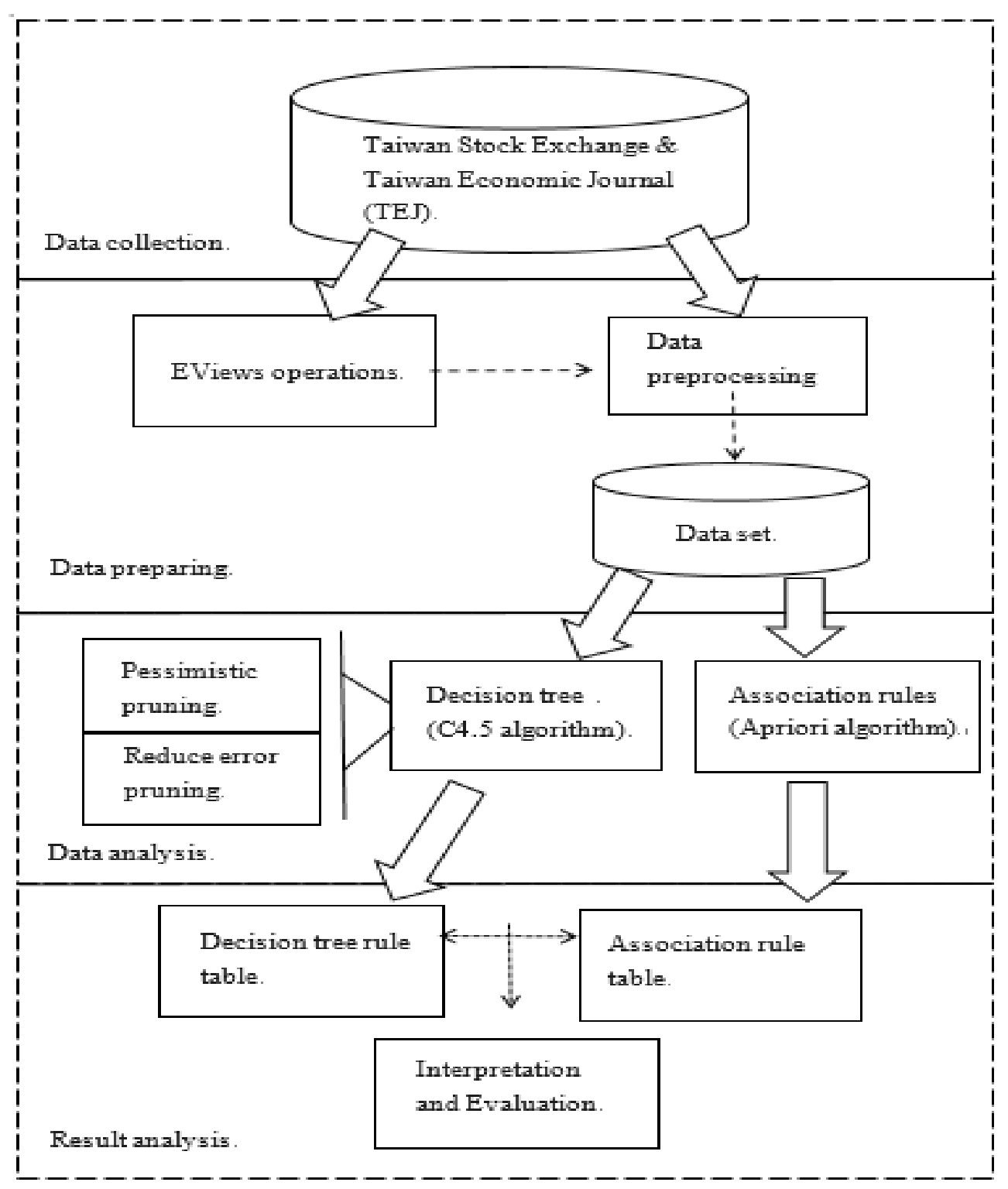

Figure 1. Research architecture.

1. Data preprocessing:

The collected data are filtered, and then the parts that do not meet the conditions or incomplete data are deleted. The data are converted into data types that can be used by subsequent analysis.

2. Decision tree analysis:

The pre-processed data is analyzed by using the J48 classifier established by the C4.5 algorithm [29] in Weka 3.8, see the Appendix A. Before performing decision tree analysis, the original data are divided into two parts. One part is used as a training set for building the model, and the other is used as the test set for testing the accuracy of the model. 
3. Analysis of association rules:

Analysis of association rules is mainly used to mine rules hidden in huge data sets. In order to avoid generating a number of rules which is too large, or rules that do not have substantial meaning, association rules usually need to be performed according to coverage (support) and accuracy (confidence) to prune. In this study, Weka 3.8's Apriori algorithm is used to set the threshold of support at $10 \%$ and the threshold of confidence at $85 \%$. This algorithm is used to iteratively operate based on the threshold of support and the threshold of confidence.

4. Interpretation and evaluation of the results:

Interpreting the rules generated by the C4.5 algorithm or the Apriori algorithm [30], if any rule that is generated by both the algorithms, it means that the value of the rule is high. Finally, it is evaluated whether each rule is useful.

\subsection{Definition of Variables}

The definitions of each variable are summarized in Table 1.

First, dependent variables:

(1) Tobin's Q

Because Tobin's $Q$ can better reflect the time value of intangible assets and money, it is commonly used to measure market performance and growth opportunities [31-33]. Tobin's $Q$ refers to the ratio of the company's equity and the market value of liabilities to the replacement cost of its assets. However, the market value of liabilities and the replacement cost of total assets are difficult to obtain [19].

Table 1. Definition of variables.

\begin{tabular}{|c|c|c|}
\hline No & Variable Name & Variable Definition \\
\hline 1 & Tobin's Q & $\begin{array}{c}\text { Common stock market value } \\
\text { +Special stock market value } \\
\text { +Book value of long-term and short-term liabilities }\end{array}$ \\
\hline 2 & Return on assets (ROA) & $\begin{array}{c}\text { book value of assets } \\
\frac{\text { Net profit before interest, tax, and depreciation }}{\text { book value of total assets }}\end{array}$ \\
\hline 3 & Return on equity (ROE) & $\frac{\text { Net profit before interest, tax, and depreciation }}{\text { Shareholders'equity }}$ \\
\hline 4 & Debt ratio (DR) & $\frac{\text { Bool value od liabilities }}{\text { Book value of liabilities }+ \text { book value of equity }}$ \\
\hline 5 & Adjustment speed $(\delta)$ & Refer to the dynamic model [34] \\
\hline 6 & Years of establishment (AGE) & Years of TEJ definition \\
\hline 7 & R\&D expense ratio (R\&D) & R\&D expense \\
\hline 8 & Dividend payout ratio (DIVIDEND) & $\begin{array}{l}\text { Tividends per ossets } \\
\text { Earninary share } \\
\text { Earning per ordinary share }\end{array}$ \\
\hline 9 & Price-earnings ratio (PER) & $\frac{\text { market price per ordinary stock }}{\text { Earnings per ordinary share }}$ \\
\hline 10 & Price-to-equity ratio (PBR) & $\frac{\text { R\&D expense }}{\text { Total assets }}$ \\
\hline 11 & Stock index change rate (ECON) & $\begin{array}{l}\text { TEJ-defined stock price index change rate8888(monthly } \\
\text { average) }\end{array}$ \\
\hline
\end{tabular}

Source: Own elaboration.

According to Tobin's $Q$ theory proposed by James Tobin [19], when the ratio is greater than 1 , it means that the company's stock price is higher than the issue cost and investors have higher willingness to invest. Therefore, "1" is used as the classification standard.

(2) Return on assets (ROA)

Return on assets is often used as one of the indicators of a company's operating performance and also represents the company's own profitability. Compared to Tobin's Q, the return on assets is more focused on the performance of internal operating capabilities. The rate of return on assets can be divided into an investment perspective and an accounting perspective. The former's formula is the net profit before interest and taxes divided by the total assets, which represents the investor's rate of return.

The economic meaning of the formula in Table 1 is how much profit a company can create by using every 1 dollar of assets. Generally, the return on assets is regarded as 
a boundary of $5 \%$, and more than $5 \%$ means that the company has a good competitive advantage. However, because the average return of the sample in this study is high, the average of $12 \%$ is used as the boundary.

(3) Return on equity (ROE)

Same as return on assets, return on equity is one of the indicators used to analyze profitability. The economic meaning of the above formula is how much profit a company can create by using every 1 dollar of capital.

Second, the independent variables:

(1) Debt ratio (DR)

In the relevant literature on capital structure, there are many different views on the measurement of debt ratios. For example, Titman and Wessels [20] proposed that the book value should be used to measure debt ratios. The argument is that it is difficult to obtain market value data. There is a high correlation between book value and market value, so using book value does not make much difference.

(2) The speed of adjustment ( $\delta$ )

If the company observes the difference between the debt ratio and the previous year's debt ratio, and the target debt ratio and the previous year's debt ratio are equal, the adjustment speed is 1 . When the adjustment speed is greater than 1 , it means that the company is over-adjusting. On the contrary, if the adjustment speed is less than 1 , it means that the adjustment is insufficient. Its value can be used as the adjustment speed for each period. The average value of 0.1 is used as the boundary on the speed of adjustment in this study.

Third, control variables:

(1) Ages (AGE)

The year of establishment of a company (AGE) usually serves as a proxy for its life cycle. The life cycle of a company will not only indirectly affect the adjustment of the capital structure, but also affect the business performance of the company. With reference to the past literature's method of distinguishing the life cycle stages, the growth period is less than 10 years, the mature period is 10 to 30 years, and the decline period is more than 30 years.

(2) $R \& D$ expense ratio $(R \& D)$

The increase in R\&D expenditure in a company has a positive relationship with Tobin's Q. Therefore, this study takes the R\&D expense ratio as the control variable.

(3) Dividend payment rate (DIVIDEND)

It is believed that the agency costs problem, the conflict of interest between shareholders and creditors and between shareholders and insiders, can be reduced through the distribution of dividends. The dividend distribution rate will indirectly affect company performance, so the dividend payment rate is included as one of the control variables.

(4) Price-earnings ratio ( $\mathrm{P} / \mathrm{E}$ ratio)

Price-earnings ratio is one of the benchmarks for investors to estimate the stock price. The concept is that the investor can expect to earn back the number of stocks purchased within the company's profitability. This study uses the P/E ratio as one of the factors to explain company performance.

(5) Stock price-to-book-value ratio (PBR)

When a company's profitability is unstable, investors cannot use the $\mathrm{P} / \mathrm{E}$ ratio to measure the future profit or loss of the stocks purchased. Investors usually use the PBR as the basis for judgment. Generally speaking, when the PBR is less than 1, it means that it is cheaper and you can consider buying it.

(6) Economy boom indicator (ECON)

Since a company's operating performance may be affected by the overall economy and boom cycle, the economic boom indicator is added as one of the control variables. This study uses the monthly average value in the changing rate of the stock price index as the economic boom indicator. 


\subsection{Decision Tree}

In this study, the widely used C4.5 algorithm is used to construct the decision tree. In the Weka software, this algorithm is applied to the J48 classifier, which is based on the C4.5 algorithm. Because the J48 classifier cannot analyze numerical target variables, all data must be converted into nominal scales according to appropriate classification standards before building the model. The detailed conversion standards are shown in Table 2.

Table 2. Variable conversion.

\begin{tabular}{|c|c|c|c|}
\hline No & Variable Name & Converted Name & Condition \\
\hline 1 & Tobin's Q & $\begin{array}{c}\text { Tobin's } Q=\text { GOOD } \\
\text { Tobin's } Q=\text { BAD }\end{array}$ & $\begin{array}{l}\text { Tobin's } Q \geq 1 \\
\text { Tobin's } Q<1\end{array}$ \\
\hline 2 & Return on assets (ROA) & $\begin{array}{c}\mathrm{ROA}=\mathrm{GOOD} \\
\mathrm{ROA}=\mathrm{BAD}\end{array}$ & $\begin{array}{l}\mathrm{ROA} \geq 12 \% \\
\mathrm{ROA}<12 \%\end{array}$ \\
\hline 3 & Return on equity (ROE) & $\begin{array}{c}\mathrm{ROE}=\mathrm{GOOD} \\
\mathrm{ROE} \geq 15 \%\end{array}$ & $\begin{array}{l}\mathrm{ROE} \geq 15 \% \\
\mathrm{ROE}<15 \%\end{array}$ \\
\hline 4 & Debt ratio (DR) & $\begin{array}{c}\text { DR = HIGH } \\
\text { DR = MODERATE } \\
\text { DR = LOW }\end{array}$ & $\begin{array}{c}\mathrm{DR} \geq 60 \% \\
60 \%>\mathrm{DR} \geq 40 \% \\
\mathrm{DR}<40 \%\end{array}$ \\
\hline 5 & Adjustment speed $(\delta)$ & $\begin{array}{c}\delta=\text { FAST } \\
\delta=\text { SLOW }\end{array}$ & $\begin{array}{l}\delta \geq 0.1 \\
\delta<0.1\end{array}$ \\
\hline 6 & Years of establishment (AGE) & $\begin{array}{l}\mathrm{AGE}=\mathrm{O} \\
\mathrm{AGE}=\mathrm{M} \\
\mathrm{AGE}=\mathrm{Y}\end{array}$ & $\begin{array}{c}\mathrm{AGE} \geq 30 \\
30>\mathrm{AGE} \geq 10 \\
\mathrm{AGE}<10\end{array}$ \\
\hline 7 & R\&D expense ratio (R\&D) & $\begin{array}{l}\text { R\&D }=\text { HIGH } \\
\text { R\&D }=\text { LOW }\end{array}$ & $\begin{array}{l}\mathrm{RD} \geq 3.44 \% \\
\mathrm{RD}<3.44 \%\end{array}$ \\
\hline 8 & Dividend payout ratio (DIVIDEND) & $\begin{array}{c}\text { DIVIDEND = HIGH } \\
\text { DIVIDEND = MODERATE } \\
\text { DIVIDEND = LOW }\end{array}$ & $\begin{array}{c}\text { DIVIDEND } \geq 70 \% \\
70 \%>\text { DIVIDEND } \geq 40 \% \\
\text { DIVIDEND }<40 \%\end{array}$ \\
\hline 9 & Price-earnings ratio (PER) & $\begin{array}{c}\text { PER = HIGH } \\
\text { PER = MODERATE } \\
\text { PER = LOW }\end{array}$ & $\begin{array}{c}\text { PER } \geq 20 \\
20>\text { PER } \geq 12 \\
\text { PER }<12\end{array}$ \\
\hline 10 & Price-to-equity ratio (PBR) & $\begin{array}{c}\mathrm{PBR}=\mathrm{HIGH} \\
\mathrm{PBR}=\mathrm{LOW}\end{array}$ & $\begin{array}{l}\mathrm{PBR} \geq 1 \\
\mathrm{PBR}<1\end{array}$ \\
\hline 11 & Stock index change rate (ECON) & $\begin{array}{l}\mathrm{ECON}=\mathrm{RISE} \\
\mathrm{ECON}=\mathrm{FALL}\end{array}$ & $\begin{array}{l}E C O N \geq 0 \\
E C O N<0\end{array}$ \\
\hline
\end{tabular}

Source: Own elaboration.

In this study, the cross-validation model was used to divide the sample into 10 equal parts, taking 1 of them in turn as the validation data set, and other samples as the training data set to build the prediction model. This repeats the calculation process 10 times. In addition, when building a decision tree, if there are too many decision nodes in the decision tree, overfitting may occur. Therefore, this study compares the pessimistic pruning and reduced error pruning used in the C4.5 algorithm.

\subsection{Association Rules}

Association rules can be used to reflect the relationship between variables. This study uses the Apriori algorithm in the Weka software to build association rules. The numerical data must be converted into nominal data in the process of the Apriori algorithm.

In order to find out useful association rules, it is necessary to set acceptable support and confidence. Support is also called coverage rate and is a metric that describes the proportion and degree being tested. The setting of support can delete the rules that occur infrequently or even meaninglessly, so this study set the support to $10 \%$. Confidence is also called accuracy rate, which means the frequency of corresponding events after meeting a 
single event in the association rules. In other words, the higher the confidence setting is, the higher the reliability of rule inference is. In this study, the confidence is set to $85 \%$.

The purpose of using association rules in this study is to find the same points as the decision tree rules or to find out if there are other different results and new findings to make up for the shortcomings of decision trees. Through these results, it provides companies with a better basis for the adjustment of their capital structure and can therefore create better company performance.

\section{Results}

The samples for this study are taken from the five-year data of listed companies in the Taiwan Economic Journal (TEJ) from 2012 to 2016. The original samples collected were 3179 , after deleting the missing values or the data with less than 5 years of listing, the effective samples are 1470. Traditional industries and the science and technology industry are the two largest groups of listed companies in Taiwan, so they are used as representative samples for analysis. Among them, traditional industries include 148 companies and 146 in the technology industry. In the following, this study's results are analyzed through decision tree analysis and association rules analysis.

\subsection{Decision Tree Analysis}

\subsubsection{Tobin's Q Decision Tree}

Tobin's $Q$ decision tree was produced with 6 decision nodes and 10 leaf nodes, see Figure 2. The ROC (receiver operating characteristic curve) area is the primary indicator for observing whether the decision tree model is properly classified. From Table 3, we can see that the ROC area of the decision tree of Tobin's $Q$ in this study is 0.808 , which has a certain accuracy.

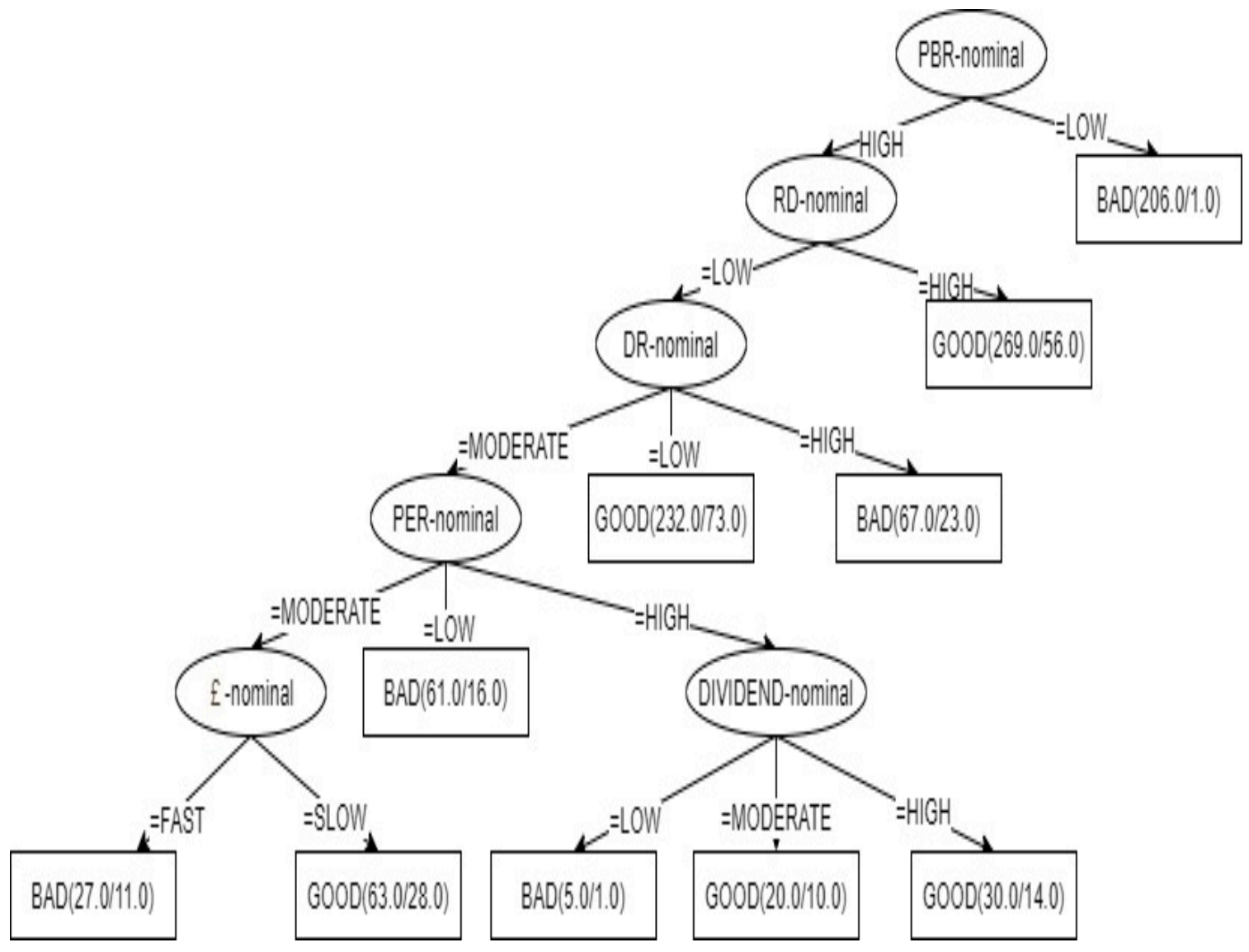

Figure 2. Tobin's $Q$ decision tree. 
Table 3. Tobin's Q decision tree accuracy rate.

\begin{tabular}{cccc}
\hline Precision & Recall & F-Measure & ROC \\
\hline 0.757 & 0.754 & 0.754 & 0.808 \\
\hline
\end{tabular}

Source: Own elaboration.

In addition to the ROC area, precision and recall are also indicators of the effectiveness of the model, which are 0.757 and 0.754 respectively. However, due to the reciprocal relationship between the two, the F-Measure, which is the weighted harmonic average, is usually used. As a comprehensive evaluation index that includes both, the results of this study show that the correct retrieval ability of this decision tree model is 0.754 .

Figure 2 is the complete decision tree of Tobin's Q. Among the 10 rules generated, there are 3 rules with high accuracy (above 80\%) and high correct number (above 200) at the same time (see Table 4), which are as follows:

Table 4. High accuracy and high correct number rules.

\begin{tabular}{ccc}
\hline Converted Name & Correct Number & Correct Rate \\
\hline PBR $=$ LOW $\rightarrow$ Tobin's Q $=$ BAD & 206 & $99.52 \%$ \\
PBR $=$ HIGH and RD $=$ HIGH $\rightarrow$ Tobin's Q = GOOD & 269 & $82.77 \%$ \\
PBR $=$ HIGH and RD $=$ LOW and DR $=$ LOW $\rightarrow$ Tobin's Q = GOOD & 232 & $76.07 \%$ \\
\hline
\end{tabular}

Source: Own elaboration.

Rule 1: $\mathrm{PBR}=\mathrm{LOW} \rightarrow$ Tobin's $\mathrm{Q}=\mathrm{BAD}$ (Correct rate: $99.52 \%$ )

Of the 207 records with a stock price-to-equity ratio of less than 1, 206 are correctly classified as Tobin's $Q$ less than 1 . That means when the stock price-to-equity ratio is low, the company's market value is usually poor. From Figure 3, we can clearly see the impact of the stock price-to-equity ratio on Tobin's $Q$ decision. When the stock price-to-equity ratio is less than 1 , only one sample has good market performance. The information gain ratio of this variable in the decision tree is extremely high.

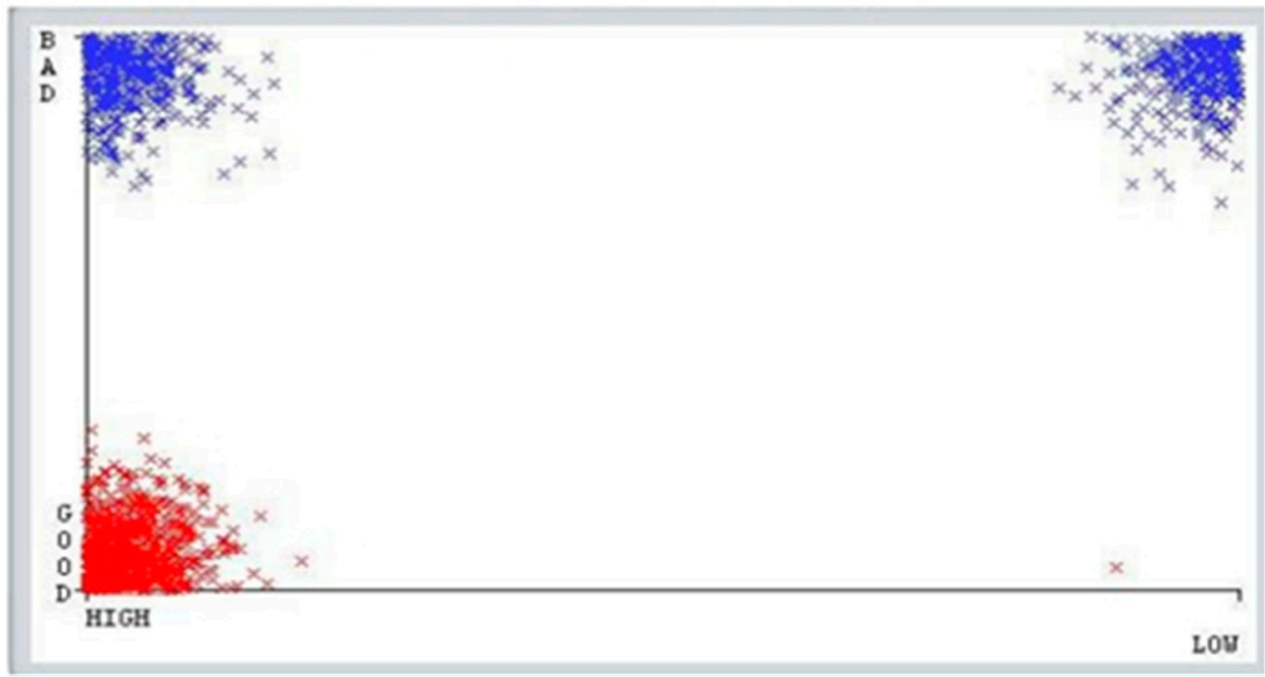

Figure 3. Tobin's $Q$ and PBR scatter diagram. $X$ axis: PBR; $Y$ axis: Tobin's $Q$.

Rule 2: $\mathrm{PBR}=\mathrm{HIGH}$ and $\mathrm{RD}=\mathrm{HIGH} \rightarrow$ Tobin's $\mathrm{Q}=\mathrm{GOOD}$ (Correct rate: $82.77 \%$ )

In the case of a stock price-to-equity ratio greater than or equal to 1 , the value of the company must also be judged by the level of the R\&D expense ratio, which shows that the current products are changing rapidly and the demand for innovation is increasing. Of the 325 records with a stock price-to-equity ratio of less than 1 and an R\&D expense ratio lower than the average, 269 were correctly classified as Tobin's $Q$ more than or equal to 1. 
In addition, it can be found that the samples covered by this rule almost exclusively belong to the technology industry, while most of the traditional industry's R\&D expense ratio is lower than the average.

Rule 3: $\mathrm{PBR}=\mathrm{HIGH}$ and $\mathrm{RD}=\mathrm{LOW}$ and $\mathrm{DR}=\mathrm{LOW} \rightarrow$ Tobin's $\mathrm{Q}=\mathrm{GOOD}$

(Correct rate: $76.07 \%$ )

When the stock price-to-equity ratio is greater than or equal to 1 , the R\&D expense ratio is lower than the average, and the debt ratio is less than $40 \%$, there will be good market performance. If you also see the debt ratio of $60 \%$ or more, you will find that when the debt ratio is high, Tobin's $Q$ will be lower.

In addition to the above three rules, there are other important rules described as follows. When the stock price-to-equity ratio is greater than or equal to $1, R \& D$ expense ratio is less than $3.44 \%$, and the debt ratio and $\mathrm{P} / \mathrm{E}$ ratio are both moderate, Tobin's $\mathrm{Q}$ will be good. A low $\mathrm{P} / \mathrm{E}$ ratio usually means that the company will have a higher return on investment. However, in the rules of the Tobin's $\mathrm{Q}$ decision tree, when the $\mathrm{P} / \mathrm{E}$ ratio is high, the R\&D expense ratio is low, and the debt ratio is moderate, then if the $\mathrm{P} / \mathrm{E}$ ratio is low, the market performance is poor. The reason is that the $\mathrm{P} / \mathrm{E}$ ratio can also be used to reflect investors' expectations of the company. If investors have positive expectations for the company's future, the $\mathrm{P} / \mathrm{E}$ ratio will be higher; otherwise it will be lower.

\subsubsection{ROA Decision Tree}

The ROA decision tree is produced with 5 decision nodes and 9 leaf nodes. As shown in Table 5, the ROC area of the ROA decision tree is 0.765 , meaning that the classification of the model is accurate. In addition, the value of the F-Measure is 0.700 , which is the lowest of the three decision tree results in this study. If the precision and the recall are 0.700 and 0.701 , we can find that this ROA decision tree retrieval system's ability to reject non-relevant information and retrieve relevant information is relatively poor, but it is still within the general standard range.

Table 5. ROA decision tree accuracy rate.

\begin{tabular}{cccc}
\hline Precision & Recall & F-Measure & ROC \\
\hline 0.700 & 0.701 & 0.700 & 0.765 \\
\hline
\end{tabular}

Source: Own elaboration.

There are 9 rules with high and correct numbers in the ROA decision tree. Among the 9 rules generated, there are 2 rules with high accuracy and high correct number at the same time, which are as follows.

Rule 1: $\mathrm{PBR}=\mathrm{LOW} \rightarrow \mathrm{ROA}=\mathrm{BAD}$ (Correct rate: $92.74 \%$ ).

The simplest rule in the ROA decision tree is that when the stock price-to-equity ratio is less than 1, ROA is poor. Same with the Tobin's $Q$ decision tree, the stock price-to-equity ratio is high for the information gain ratio to the ROA decision tree, making it easy to identify companies that are underperforming.

Rule 2: $\mathrm{PBR}=\mathrm{HIGH}, \delta=\mathrm{SLOW}, \mathrm{AGE}=\mathrm{M}$ and $\mathrm{DR}=\mathrm{LOW} \rightarrow \mathrm{ROA}=\mathrm{GOOD}$

(Correct rate: $78.50 \%$ )

ROA is usually above average when the stock price-to-equity ratio is greater than or equal to 1 , the rate of adjustment is below average, the number of years of establishment is between 10 and 30 years, and the debt ratio is less than $40 \%$. Presumably, the larger companies will have lower borrowing costs, so usually the debt ratio will be higher. However, the development of mature companies in the market has a certain share, so it is easy to obtain equity funds from the capital market. Thus, these companies have low debt ratios and still have good business performance.

\subsubsection{ROE Decision Tree}

The ROE decision tree results have a total of 7 decision nodes and 13 leaf nodes, and achieve a training accuracy rate of $77.89 \%$ and a test accuracy rate of $75.65 \%$. As shown in 
Table 6 , the ROC area of the ROE decision tree is 0.785 , and more than 0.7 indicates that the classification of this model is accurate. The precision rate is 0.748 and the recall rate is 0.756 , and these are also high. The value of the F-Measure representing the decision tree's ability to correctly retrieve relevant data is 0.745 , indicating that this decision tree model has certain capabilities in rejecting non-relevant data or retrieving relevant data.

Table 6. ROE decision tree accuracy rate.

\begin{tabular}{cccc}
\hline Precision & Recall & F-Measure & ROC \\
\hline 0.748 & 0.756 & 0.745 & 0.785 \\
\hline
\end{tabular}

Source: Own elaboration.

Among the 13 rules generated, there are 3 rules with high correct prediction rates and correct number, which are described as follows:

Rule 1: PBR $=$ HIGH and PER $=$ LOW $\rightarrow$ ROE $=$ GOOD (Correct rate: $91.89 \%$ ).

Of the 185 sample companies whose stock price-to-equity ratio is greater than or equal to 1 and whose PE ratio is less than 12,170 companies are correctly classified as ROE greater than $15 \%$. Usually ROE will also be good.

Rule 2: $\mathrm{PBR}=\mathrm{HIGH}$ and $\mathrm{PER}=\mathrm{MODERATE} \rightarrow \mathrm{ROE}=\mathrm{GOOD}$

(Correct rate: $85.07 \%$ )

When the stock price-to-equity ratio is greater than or equal to 1 and the $\mathrm{P} / \mathrm{E}$ ratio is between 12 and 20, there will be a good ROE. It means that the ability of the company to make money for shareholders is relatively high.

Rule 3: $\mathrm{PBR}=\mathrm{LOW} \rightarrow \mathrm{ROE}=\mathrm{BAD}$ (Correct rate: $76.84 \%$ )

When the stock price-to-equity ratio is less than 1 , it means that the market price of the stock is lower than the book. Generally, the company's ability to profit for shareholders is also poor.

\subsection{Associate Rules Analysis}

\subsubsection{Tobin's Q Association Rules}

As shown in Table 7, when the accuracy rate is set to $85 \%$ and the minimum coverage rate is $10 \%$, there are 17 association rules with Tobin's $Q$ as the target variable generated and the first 8 rules have the highest accuracy rate $(100 \%)$. This shows that when the input variable classification is established, the target variable Tobin's $Q=B A D$ is almost certainly established.

Table 7. Tobin's $Q$ association rules.

\begin{tabular}{|c|c|c|}
\hline Input Variable & Target Variable & Accuracy Rate \\
\hline $\mathrm{PBR}=\mathrm{LOW}, \delta=\mathrm{SLOW}$ & Tobin's $Q=$ BAD & 1.00 \\
\hline $\mathrm{PBR}=\mathrm{LOW}, \mathrm{R} \& \mathrm{D}=\mathrm{LOW}, \delta=\mathrm{SLOW}$ & Tobin's $\mathrm{Q}=\mathrm{BAD}$ & 1.00 \\
\hline $\mathrm{PBR}=\mathrm{LOW}, \mathrm{R} \& \mathrm{D}=\mathrm{LOW}, \mathrm{AGE}=\mathrm{O}$ & Tobin's $\mathrm{Q}=\mathrm{BAD}$ & 1.00 \\
\hline $\mathrm{PBR}=\mathrm{LOW}, \mathrm{AGE}=\mathrm{O}, \mathrm{ECON}=\mathrm{RISE}$ & Tobin's $Q=$ BAD & 1.00 \\
\hline $\mathrm{PBR}=\mathrm{LOW}, \mathrm{ECON}=\mathrm{RISE}$ & Tobin's $\mathrm{Q}=\mathrm{BAD}$ & 1.00 \\
\hline $\mathrm{PBR}=\mathrm{LOW}$ & Tobin's $\mathrm{Q}=\mathrm{BAD}$ & 1.00 \\
\hline $\mathrm{PBR}=\mathrm{LOW}, \mathrm{R} \& \mathrm{D}=\mathrm{LOW}$ & Tobin's $\widehat{Q}=\mathrm{BAD}$ & 1.00 \\
\hline $\mathrm{PBR}=\mathrm{LOW}, \mathrm{ECON}=\mathrm{RISE}$ & Tobin's $\widehat{Q}=\mathrm{BAD}$ & 1.00 \\
\hline $\mathrm{PBR}=\mathrm{LOW}, \mathrm{R} \& \mathrm{D}=\mathrm{LOW}, \mathrm{ECON}=\mathrm{RISE}$ & Tobin's $\mathrm{Q}=\mathrm{BAD}$ & 0.99 \\
\hline $\mathrm{PBR}=\mathrm{LOW}, \mathrm{DIVIDEND}=\mathrm{HIGH}$ & Tobin's $\mathrm{Q}=\mathrm{BAD}$ & 0.99 \\
\hline $\mathrm{PBR}=\mathrm{LOW}, \mathrm{DR}=\mathrm{LOW}$ & Tobin's $\mathrm{Q}=\mathrm{BAD}$ & 0.99 \\
\hline $\mathrm{PBR}=\mathrm{HIGH}, \mathrm{DR}=\mathrm{LOW}, \mathrm{R} \& \mathrm{D}=\mathrm{HIGH}, \mathrm{ECON}=\mathrm{RISE}$ & Tobin's Q = GOOD & 0.89 \\
\hline $\mathrm{PBR}=\mathrm{HIGH}, \mathrm{DR}=\mathrm{LOW}, \mathrm{R} \& \mathrm{D}=\mathrm{HIGH}, \mathrm{AGE}=\mathrm{M}$ & Tobin's Q = GOOD & 0.89 \\
\hline $\mathrm{PBR}=\mathrm{HIGH}, \mathrm{DR}=\mathrm{LOW}, \mathrm{R} \& \mathrm{D}=\mathrm{HIGH}, \delta=\mathrm{SLOW}, \mathrm{ECON}=\mathrm{RISE}$ & Tobin's $\widehat{Q}=$ GOOD & 0.88 \\
\hline $\mathrm{PBR}=\mathrm{HIGH}, \mathrm{DR}=\mathrm{LOW}, \mathrm{R} \& \mathrm{D}=\mathrm{HIGH}$ & Tobin's $\widehat{Q}=$ GOOD & 0.88 \\
\hline $\mathrm{PBR}=\mathrm{HIGH}, \mathrm{DR}=\mathrm{LOW}, \mathrm{R} \& \mathrm{D}=\mathrm{HIGH}, \delta=\mathrm{SLOW}$ & Tobin's Q = GOOD & 0.86 \\
\hline $\mathrm{PBR}=\mathrm{HIGH}, \mathrm{DR}=\mathrm{LOW}, \mathrm{R} \& \mathrm{D}=\mathrm{HIGH}, \mathrm{AGE}=\mathrm{M}, \mathrm{ECON}=\mathrm{RISE}$ & Tobin's Q = GOOD & 0.85 \\
\hline
\end{tabular}


Table 8 shows the common results of Tobin's Q's association rules and decision tree. It can be seen that if a company's stock price-to-equity ratio is less than 1, its market performance will be poor. However, some implicit rules that are not shown in the decision tree will be further revealed in the association rules. For example, at the same time that the stock price-to-equity ratio is low, even if the debt ratio is adjusted slowly, its Tobin's Q will still be low. Presumably because the investor is not optimistic about this type of company, the company cannot obtain equity funds, and the company also cannot use excessive debt adjustments, this results in poor performance. When the stock price-to-equity ratio is low and the R\&D investment is low, the market performance will be poor. In addition, when companies issue high stock interest rates or low debt ratios, but the ordinary stock market value is low, they will have poor market performance.

Table 8. Tobin's $Q$ the same rules in decision tree and association rules.

\begin{tabular}{clc}
\hline Rule No & \multicolumn{1}{c}{ Input Variable } & Target Variable \\
\hline 1. & $\mathrm{PBR}=\mathrm{LOW}$ & Tobin's $\mathrm{Q}=\mathrm{BAD}$ \\
\hline 2. & $\mathrm{PBR}=\mathrm{HIGH}, \mathrm{RD}=\mathrm{HIGH}$ & Tobin's $\mathrm{Q}=\mathrm{GOOD}$ \\
\hline
\end{tabular}

The Tobin's $\mathrm{Q}=$ GOOD's association rule, same as the decision tree, is that the stock price-to-equity ratio is greater than or equal to 1 and the $R \& D$ expense ratio is higher than the average, indicating that the investment in $R \& D$ expenses has a great impact on the company's value.

In the Tobin's $Q=$ GOOD's association rule, there is a point that is different from the decision tree. When the stock price-to-equity ratio in the decision tree is greater than or equal to 1 , the $R \& D$ expense ratio must be used to determine whether the additional decision nodes are required. However, in the association rules, the debt ratio is less than $40 \%$ in each Tobin's $Q$ when it is good, so the debt ratio is also an important basis for evaluating market performance.

\subsubsection{ROA Association Rules}

As shown in Table 9, there are a total of 9 association rules with ROA as the target variable, and all of the lifts are higher than 1, which is a strong association rule. You can find the result of these association rules and decision trees is exactly the same, that is, when the stock price-to-equity ratio is less than 1, the ROA will be lower than the average.

Table 9. ROA association rules.

\begin{tabular}{|c|c|c|c|}
\hline Input Variable & Target Variable & Accuracy Rate & Lift \\
\hline $\mathrm{PBR}=\mathrm{LOW}, \mathrm{R} \& \mathrm{D}=\mathrm{LOW}, \mathrm{AGE}=\mathrm{O}$ & $\mathrm{ROA}=\mathrm{BAD}$ & 0.97 & 1.71 \\
\hline $\mathrm{PBR}=\mathrm{LOW}, \mathrm{DIVIDEND}=\mathrm{HIGH}$ & $\mathrm{ROA}=\mathrm{BAD}$ & 0.96 & 1.68 \\
\hline $\mathrm{PBR}=\mathrm{LOW}, \mathrm{AGE}=\mathrm{O}$ & $\mathrm{ROA}=\mathrm{BAD}$ & 0.95 & 1.67 \\
\hline $\mathrm{PBR}=\mathrm{LOW}, \mathrm{R} \& \mathrm{D}=\mathrm{LOW}, \mathrm{ECON}=\mathrm{RISE}$ & $\mathrm{ROA}=\mathrm{BAD}$ & 0.94 & 1.65 \\
\hline $\mathrm{PBR}=\mathrm{LOW}, \mathrm{R} \& \mathrm{D}=\mathrm{LOW}$ & $\mathrm{ROA}=\mathrm{BAD}$ & 0.93 & 1.63 \\
\hline $\mathrm{PBR}=\mathrm{LOW}, \mathrm{ECON}=\mathrm{RISE}$ & $\mathrm{ROA}=\mathrm{BAD}$ & 0.93 & 1.62 \\
\hline $\mathrm{PBR}=\mathrm{LOW}$ & $\mathrm{ROA}=\mathrm{BAD}$ & 0.92 & 1.62 \\
\hline $\mathrm{PBR}=\mathrm{LOW}, \mathrm{DR}=\mathrm{LOW}$ & $\mathrm{ROA}=\mathrm{BAD}$ & 0.91 & 1.59 \\
\hline $\mathrm{PBR}=\mathrm{LOW}, \delta=\mathrm{SLOW}$ & $\mathrm{ROA}=\mathrm{BAD}$ & 0.91 & 1.59 \\
\hline
\end{tabular}

Source: Own elaboration.

Observed from the association rules, other variable relationships that are not shown in the decision tree rules emerge, such as when the stock price-to-equity ratio is less than 1 and the ROA is less than $12 \%$, in terms of controlling variables, the company may have a low R\&D expense rate, a long establishment year, or a high dividend payment rate. The characteristic of high dividend payment rate is, because the equity of the long-established company is mostly dispersed in the market, there is a higher dividend payment to satisfy 
shareholders. If there is no innovative plan, the ROA of the company tends to stabilize or gradually decline. The ROA decision tree rules are consistent with the association rules with an accuracy rate of more than $85 \%$, which means that the results are more reliable and have more reference value.

\subsubsection{ROE Association Rules}

There are 20 association rules generated by using ROE as the target variable, among which there are 2 rules which are the same as the decision tree rules. One is when the stock price-to-equity ratio is greater than or equal to 1 and the $\mathrm{P} / \mathrm{E}$ ratio is lower than 12 , the $\mathrm{ROE}$ will be higher than $15 \%$. Another rule is that when the stock price-to-equity ratio is greater than or equal to 1 and the $\mathrm{P} / \mathrm{E}$ ratio is between 12 and 20, the ROE will be higher than $15 \%$.

When the target ROE is higher than $15 \%$, there are several rules that are different from the decision tree results. For example, based on not considering the P/E ratio, when the stock price-to-equity ratio is greater than or equal to 1 , the $R \& D$ expense ratio is lower than the average and the number of years established is between 10 and 30 years, or the dividend payout ratio is higher than $40 \%$ with the appropriate debt ratio and adjustment speed, all will have a good ROE.

From the above results, since the generation of decision tree rules is useful for improving company performance, when some variable data is missing or unavailable, you can make up for these deficiencies through association rules to improve the accuracy of decision-making.

\section{Conclusions}

According to the findings of the paper, a company tends to have better performance when its debt ratio is low, and Tobin's $Q$ and ROA will turn worse as the ratio gets higher. However, maybe because of the financial leverage, ROE will not decrease when the ratio is high but will increase instead. In addition, this research found that adjustment speed is negatively related to company performance, meaning that even though a company is more flexible in adjusting itself, it might still perform badly since it is deviating from its optimum leverage. This research found that not only capital structure, but other variables such as price-earnings ratio, research and development expense ratio, and dividend payout ratio also determine a company's performance. Liabilities are one of the company's main sources of funds. The way in which debt financing is used must be undertaken by the company to bear the relative risks, and the adjustment of the debt ratio will also generate other external costs. Therefore, this study uses decision trees based on the dynamic capital structure theory to analyze and observe the relationship between the debt ratio and the adjustment speed to the optimal debt ratio impacting company performance. This study also uses association rules to find out the important rules not in decision trees to assist the decision tree results. The above prediction model for company sustainability performance is recommended for managers to keep in mind and to work hard to follow.

This research applies data mining technology to explore the relationship between dynamic capital structure and company performance, and it is hoped that companies can have more efficient capital structure utilization. This research establishes a dynamic capital structure prediction model for company sustainability performance. The main contributions of this research are as follows:

1. Using the decision tree method in data mining to explore the relationship between dynamic capital structure and company performance, this study examines whether the debt ratio that the company continuously adjusts over time to achieve the optimal capital structure is the determining factor of company performance.

2. Because the decision tree observes the overall rules in the form of a single variable, the association rules are also used to analyze whether there are hidden association rules between the variables. The company can be more efficient to improve company performance by using the rules. 
In future research, there are also many other data mining techniques, such as artificial neural network, Bayes' theorem, and so on, which can be used in this field. Perhaps empirical studies could also be tried as a field study.

Author Contributions: Conceptualization, K.-C.C., M.-J.H. and C.-J.H.; methodology, K.-C.C., M.-J.H., C.-J.H., C.-K.C. and M.-C.W.; software, M.-J.H., C.-K.C. and C.-J.H.; validation, K.-M.L., H.-M.W. and M.-C.W.; formal analysis, K.-M.L. and H.-M.W.; investigation, M.-C.W. and H.-M.W.; resources, K.-C.C. and H.-M.W.; data curation, K.-C.C., C.-K.C. and M.-J.H.; writing-original draft preparation, M.-J.H., K.-M.L. and M.-C.W.; writing-review and editing, C.-J.H., K.-C.C. and H.-M.W.; project administration, K.-C.C., M.-J.H., C.-K.C. and M.-C.W. All authors have read and agreed to the published version of the manuscript.

Funding: This research received no external funding.

Institutional Review Board Statement: Not applicable.

Informed Consent Statement: Not applicable.

Data Availability Statement: This study uses Taiwan's listed companies as the research objects. The data of this study were taken from the 5-year data of listed companies in the Taiwan Economic Journal (TEJ). The data are collected from 2012 to the end of 2016 and excluded those with incomplete research variables that cannot be calculated.

Conflicts of Interest: The authors declare that they have no conflict of interest.

Ethical Approval: This paper does not contain any studies with human participants or animals performed by any of the authors.

\section{Appendix A}

C4.5 is an algorithm used to generate a decision tree developed by Ross Quinlan [35]. C4.5 is an extension of Quinlan's earlier ID3 algorithm. The decision trees generated by C4.5 can be used for classification, and for this reason, C4.5 is often referred to as a statistical classifier. In 2011, authors of the Weka machine-learning software described the C4.5 algorithm as "a landmark decision tree program that is probably the machine learning workhorse most widely used in practice to date" [36].

At each node of the tree, C4.5 chooses the attribute of the data that most effectively splits its set of samples into subsets enriched in one class or the other. The splitting criterion is the normalized information gain (difference in entropy). The attribute with the highest normalized information gain is chosen to make the decision. The C4.5 algorithm then recurses on the partitioned sublists.

\section{References}

1. Callahan, C.; Soileau, J. Does Enterprise Risk Management enhance operating performance. Adv. Account. 2017, 37, 122-139. [CrossRef]

2. Berry-Stölzle, T.R. Enterprise risk management and the cost of capital. J. Risk Insur. 2018, 85, 159-201. [CrossRef]

3. Ramalingegowda, S.; Yu, Y. The role of accounting conservatism in capital structure adjustments. J. Account. Audit. Financ. 2021, 36, 223-248. [CrossRef]

4. Dierker, M.; Lee, I.; Seo, S. Risk changes and external financing activities: Tests of the dynamic trade-off theory of capital structure. J. Emp. Financ. 2019, 52, 178-200. [CrossRef]

5. Selman, J.R.; Schneider, R. The impact of life-cycle cost management on portfolio strategies. J. Facil. Manag. 2005, 3, 173-183. [CrossRef]

6. Ardalan, K. Capital structure theory: Reconsidered. Res. Int. Bus. Financ. 2017, 39, 696-710. [CrossRef]

7. Modigliani, F.; Miller, M.H. Corporate Income Taxes and the Cost of Capital A Correction. Am. Econ. Rev. 1963, 53, 433-443.

8. Myers, S.C.; Majluf, N.S. Corporate Financing and Investment Decisions When Firms Have Information That Investors Do Not Have. J. Financ. Econ. 1984, 13, 187-221. [CrossRef]

9. Fischer, E.O.; Heinkel, R.; Zechner, J. Dynamic Capital Structure Choice: Theory and Tests. J. Financ. 1989, 44, 19-40. [CrossRef]

10. Li, D.; Jiang, Q.; Mai, Y. Board interlock and capital structure adjustment: Evidence from China. Account. Financ. 2019, 59, 1893-1922. [CrossRef]

11. Lin, S.; Ma, Y.; Zou, H. Enhanced Youden's index with net benefit: A feasible approach for optimal-threshold determination in shared decision making. J. Eval. Clin. Pract. 2020, 26, 551-558. [CrossRef] 
12. Dai, N.; Piccotti, L.R. Required return on equity when capital structure is dynamic. Financ. Manag. 2020, 49, 265-289. [CrossRef]

13. Harlow, H.D. Knowledge management strategy (KMS) for Data analytics and intellectual capital. Meditari Account. Res. 2018, 26, 400-419. [CrossRef]

14. Elsas, R.; Florysiak, D. Dynamic Capital Structure Adjustment and the Impact of Fractional Dependent Variables. J. Financ. Quant. Anal. 2015, 50, 1105-1133. [CrossRef]

15. Brennan, M.J.; Schwartz, E.S. Corporate Income Taxes, Valuation, and the Problem of Optimal Capital Structure. J. Bus. 1978, 51, 103-114. [CrossRef]

16. Kane, A.; Marus, A.J.; McDonald, R.L. Debt Policy and the Rate of Return Premium to Leverage. J. Financ. Quant. Anal. 1985, 20, 479-499. [CrossRef]

17. Jiang, X.; Ding, H.; Shi, H.; Li, C. Novel QoS optimization paradigm for IoT systems with fuzzy logic and visual information mining integration. Neural Comput. Appl. 2020, 32, 16427-16443. [CrossRef]

18. Laghari, F.; Chengang, Y. Investigate in working capital management and financial constraints: Empirical evidence on corporate performance. Int. J. Manag. Financ. 2019, 15, 164-190.

19. Tobin, J. A General Equilibrium Approach to Monetary Theory. J. Money Credit Bank. 1969, 1, 15-29. [CrossRef]

20. Titman, S.; Wessels, R. The Determinants of Capital Structure Choice. J. Financ. 1988, 42, 1-19. [CrossRef]

21. Berger, A.N.; Bonaccorsi, E. Capital Structure and Firm Performance: A New Approach to Testing Agency Theory and an Application to the Banking Industry. J. Bank. Financ. 2006, 30, 1065-1102. [CrossRef]

22. Dao, B.; Ta, T. A meta-analysis: Capital structure and firm performance. J. Econ. Develop. 2020, 22, 111-129. [CrossRef]

23. Huang, M.J.; Chen, M.Y.; Lee, S.C. Integrating Data Mining with Case-based Reasoning for Chronic Diseases Prognosis and Diagnosis. Expert Syst. Appl. 2007, 32, 856-867. [CrossRef]

24. Bolloju, N.; Khalifa, M.; Turban, E. Integrating knowledge management into enterprise environments for the nest generation decision support. Decis. Support. Syst. 2002, 33, 163-176. [CrossRef]

25. Bose, I.; Mahapatra, R. Business data mining-A machine learning perspective. Inform. Manag. 2001, 39, 211-225. [CrossRef]

26. Dastyar, B.; Kazemnejad, H.; Sereshgi, A.A.; Jabalameli, M.A. Using Data Mining Techniques to Develop Knowledge Management in Organizations: A Review. J. Eng. Proj. Prod. Manag. 2017, 7, 80-89. [CrossRef]

27. Cios, K.J.; Moore, G.W. Uniqueness of medical data mining. Artif. Intell. Med. 2002, 26, 1-24. [CrossRef]

28. Huang, M.J.; Sung, H.S.; Hsieh, T.J.; Wu, M.C.; Chung, S.H. Applying data-mining techniques for discovering association rules. Soft Comput. 2019, 24, 8069-8075. [CrossRef]

29. Alos, A.; Dahrouj, Z. Decision tree matrix algorithm for detecting contextual faults in unmanned aerial vehicles. J. Intell. Fuzzy Syst. 2020, 1-11. [CrossRef]

30. Zhan, Y.; Tan, K.H.; Huo, B. Bridging customer knowledge to innovative product development: A data mining approach. Int. J. Prod. Res. 2019, 57, 6335-6350. [CrossRef]

31. Lang, L.; Ofek, E.; Stulz, R.M. Leverage, Investment, and Firm Growth. J. Financ. Econ. 1996, 40, 3-29. [CrossRef]

32. Demsetz, H.; Villalonga, B. Ownership Structure and Corporate Performance. J. Corp. Financ. 2001, 7, 209-233. [CrossRef]

33. La Porta, R.; Lopez-De-Silanes, F.; Shleifer, A.; Vishny, R. Investor Protection and Corporate Valuation. J. Financ. 2002, 57, 1147-1170. [CrossRef]

34. Drobetz, W.; Wanzenried, G. What Determines the Speed of Adjustment to the Target Capital Structure? Appl. Financ. Econ. 2006, 16, 941-958. [CrossRef]

35. Quinlan, J.R. C4.5: Programs for Machine Learning; Morgan Kaufmann Publishers: Burlington, MA, USA, 1993.

36. Witten, L.; Frank, E.; Hall, M. Data Mining: Practical Machine Learning Tools and Techniques; Morgan Kaufmann: San Francisco, CA, USA, 2011. 